\title{
Càncer ginecològic i exercici físic
}

\author{
AnTONi Llueca (1lueca@uji.es) \\ Universitat Jaume I
}

\section{Introducció}

El càncer constitueix la primera causa de mort en els països industrialitzats. Es calcula que una de cada quatre morts als EUA són a causa del càncer. L'Agència Internacional per a la Investigació del Càncer (International Agency for Research on Cancer, IARC), estima que en el món es diagnostiquen 14,1 milions de nous casos de càncer a l'any. Segons la mateixa agència, es van produir gairebé 8,2 milions de morts per culpa d'aquesta malaltia en 2012 i, aproximadament 32,6 milions de persones vivien amb càncer en tot el món l'esmentat any (Ferlay i altres, 2014).

La incidència de càncer a Espanya l'any 2012 va ser de 215.534 casos, amb una taxa estandarditzada per edat de 215 casos anuals de càncer per cada 100.000 habitants. Es van produir 102.762 morts causades pel càncer i 581.688 persones visqueren amb la malaltia a Espanya aquell any. El risc de desenvolupar un càncer abans dels 75 anys per a un espanyol és del 25\%, és a dir, un de cada quatre espanyols desenvoluparà un càncer al llarg de la seua vida (Ferlay i altres, 2014). Les localitzacions de càncer més frequients a Espanya es reflecteixen en la figura 1.

\begin{tabular}{|c|c|c|c|}
\cline { 2 - 4 } \multicolumn{1}{c|}{} & Home & Dona & Ambdós sexes \\
\hline $1 \mathrm{r}$ & Pròstata & Mama & Colorectal \\
\hline $2 \mathrm{n}$ & Pulmó & Colorectal & Pròstata \\
\hline $3 \mathrm{r}$ & Colorectal & Cos de l'úter & Pulmó \\
\hline $4 \mathrm{rt}$ & Bufeta & Pulmó & Mama \\
\hline 5 é & Estómac & Ovari & Bufeta \\
\hline
\end{tabular}

Figura 1. Localitzacions de càncer més freqüents a Espanya. Font: Ferlay i altres (2014).

Com s'ha vist al llarg dels anys, la incidència del càncer en tot el món creix, tot i que també augmenta al mateix ritme el nombre de supervivents a causa de les millores en el diagnòstic, en forma de diagnòstics cada vegada més precoços i a les noves teràpies que inclouen la cirurgia, la quimioteràpia i la radioteràpia (Pollock i altres, 2003).

Com que el càncer s'associa amb l'edat, la major part dels supervivents són majors de 65 anys. A més, quasi la meitat són supervivents de càncer de mama i de pròstata. Així mateix, el $10 \%$ són supervivents de càncers hematològics, d'endometri i de còlon (Hewitt i altres, 2006).

A pesar de l'èxit en les tècniques de diagnòstic i tractament del càncer, la prevenció primària del càncer constitueix una àrea de gran interès, tant per a la ciència com per a la política sanitària i l'economia d'una població. Sense menystenir la càrrega genètica, la influència que puga tenir l'estil de vida i el medi ambient en el desenvolupament del càncer sembla que és molt important (Daley i altres, 2007). 
La identificació dels factors de risc i de l'estil de vida associats al desenvolupament del càncer, l'educació de la població sobre aquests factors de risc i l'actuació sobre els considerats factors de risc, faran que en un futur es puga reduir la xifra total de casos de càncer. Fins ara, s'han identificat nombrosos factors de risc associats amb el desenvolupament del càncer (Figura 2) i sobre els quals podem actuar. Entre aquests s'inclouen la conducta sexual, l'addicció a drogues, el tabac, l'obesitat, la baixa ingesta de verdures i fruites i la inactivitat física (Schmitz i altres, 2010).

Al mateix temps, també hi ha evidència científica que l'exercici físic pot millorar el control i la supervivència global almenys d'alguns tipus de càncer, com succeeix amb el càncer de còlon i el de mama (Holmes i altres, 2005).

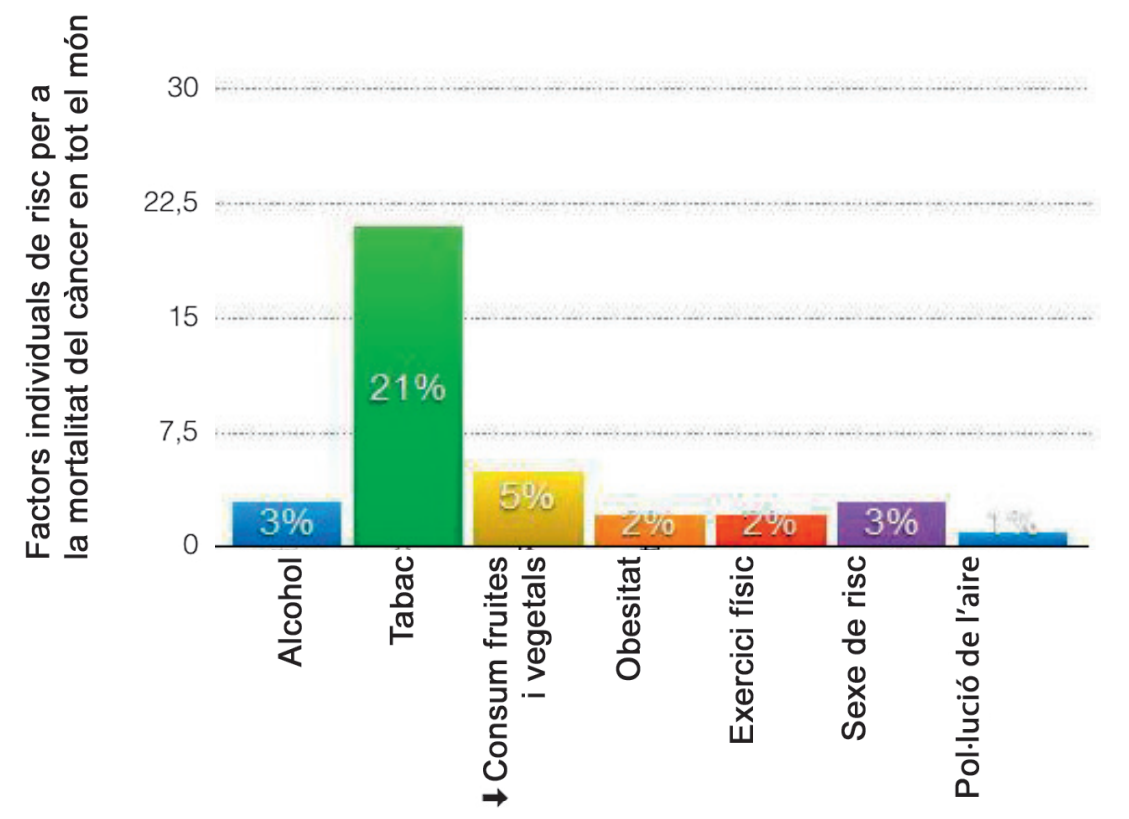

Figura 2. Taula de riscos individuals de mortalitat de tots els càncers en el món. Font: Weiderpass (2010).

De la mateixa manera, l'exercici físic pot millorar la qualitat de vida dels supervivents del càncer tot ajudant a mitigar els efectes secundaris, físics i psicològics, produïts pels agressius tractaments.

L'objectiu d'aquest treball és aprofundir en l'efecte de l'activitat física tant en la prevenció del càncer com en la qualitat de vida dels pacients que estan en ple tractament contra el càncer, així com dels que hi han sobreviscut. 


\section{Activitat física}

L'activitat física es defineix com qualsevol moviment corporal produït en contraure's els músculs esquelètics (Caspersen i altres, 1985). Així mateix, es defineixen quatre tipus d'activitat física: a) l'ocupacional, definida com l'activitat física realitzada durant el treball durant un període de temps d'unes vuit hores i que pot incloure múltiples activitats com ara caminar, alçar-se, empentar, etc.; b) la domèstica, definida com l'activitat física realitzada a casa i que inclou les obligacions típiques de la llar i l'atenció als xiquets; c) la del transport, que és l'activitat física realitzada en desplaçar-se per diferents motius com ara caminar o anar en bicicleta; i $d$ ) la recreativa, que fa referència a l'activitat física realitzada per plaer i que pot incloure una infinitat d'activitats com ara córrer, escalar, nadar, etc (Caspersen i altres, 1985).

Al mateix temps, l'activitat física pot ser de diferent intensitat, i llavors trobem activitat física suau, moderada o intensa.

Per a categoritzar objectivament l'activitat física es necessiten definir quatre variables: la frequiència, la intensitat, el temps dedicat i el tipus d'activitat física. La freqüència es refereix al nombre de dies a la setmana en què es practica activitat física. La intensitat mesura com és d'extenuant l'activitat física que realitzem. Per a mesurar la intensitat es va introduir el concepte de MET (equivalent metabòlic de despesa d'energia) de manera que 1-MET equival a l'esforç d'estar assegut, i 18-MET equivalen a córrer a un ritme de menys de cinc minuts el quilòmetre. El temps es mesura d'acord amb el nombre d'hores que dediquem cada dia a l'activitat física. El tipus es defineix per la classe d'activitat física que realitzem i que sovint inclou exercicis aeròbics, de flexibilitat, etc. Tota aquesta categorització objectiva de l'activitat física és el que constitueix el principi FITT (Frecuency, Intensity, Time and Type, Thompson i altres, 2010) i que servirà per a la definició, quantificació i prescripció de l'exercici físic, tant per al clínic com per a entrenadors. Tanmateix, des del punt de vista epidemiològic, continuarem categoritzant l'activitat física en ocupacional, domèstica, de transport i recreativa.

\section{Mecanismes biològics que relacionen l’activitat física i el càncer}

Són moltes les hipòtesis que relacionen la carcinogènesi amb l'activitat física, però la majoria d'aquestes no aconsegueixen separar l'activitat física del sobrepès i de l'obesitat. En una persona amb sobrepès, els nivells d'hormones sexuals, principalment estrògens $i$ andrògens, apareixen elevats per damunt de la normalitat, així com apareix una disminució de les proteïnes transportadores per aquestes. També es produeix en aquestes persones un augment de la resistència a la insulina, de factors de creixement relacionats amb la insulina (insulin growth factor-1) i de productes de degradació de la inflamació (interleukina-6, proteïna $\mathrm{C}$ Reactiva o factor de necrosi tumoral alfa). Tots aquests factors estan relacionats amb la carcinogènesi de determinats càncers. Així, l'augment dels nivells d'andrògens i estrògens es relaciona amb l'aparició de càncers de mama i d'endometri.

L'augment de la resistència a la insulina pot estar relacionat amb l'aparició de càncers d'endometri, mama, còlon i, possiblement, ovari (Key i altres, 2013, Il'yasova i altres, 2005). Com que l'exercici físic disminueix l'obesitat i abaixa el percentatge de greix corporal, farà que disminuïsca la quantitat d'hormones sexuals circulants i la quantitat de productes 
inflamatoris, així com la resistència a la insulina. D’aquesta manera, actuarà com a prevenció primària per a l'aparició dels càncers que s'hi relacionen. Segurament, hi ha mecanismes pels quals l'exercici físic per ell mateix produeix un efecte directe beneficiós sobre l'aparició de nous càncers, tot i que això està encara per provar científicament (Gatti i altres, 2012).

Un altre mecanisme que possiblement relaciona l'aparició de càncer amb l'exercici físic seria l'efecte de l'exercici sobre el sistema immunològic, l'estrès oxidatiu i la capacitat de reparació de l'ADN. S'ha vist que, durant l'exercici físic moderat, es produeix un augment dels limfòcits $\mathrm{T}$, de neutròfils i d'altres components del sistema immune, i que aquest efecte és acumulatiu amb els següents entrenaments. Encara que la relació de l'exercici amb el sistema immunològic és complexa $i$ hi ha poques evidències d'aquesta, es creu que l'activitat física faria augmentar les defenses de l'organisme i, per tant, disminuiria el risc de càncer.

És ben sabut que l'exercici físic produeix una gran quantitat de productes derivats de l'oxidació de processos metabòlics i que aquests poden causar danys en l'ADN que alhora es relacionarien amb l'aparició de càncers en produir-se mutacions de l'ADN. No obstant això, també és veritat que les lesions en l'ADN causades per l'exercici físic s'acompanyen de processos de reparació de l'ADN estimulats per l'augment de l'activitat física. De la relació entre el dany en l'ADN produït per l'exercici i l'estimulació dels mecanismes de reparació de l'ADN, en dependrà l'efecte que puga produir l'activitat física sobre l'aparició de nous càncers (Sato i altres, 2003; Cash i altres, 2013).

\section{Història natural del càncer i l'activitat física}

Hi ha un model predefinit del paper de l'activitat física en la història natural del càncer que el divideix en dues etapes principals: l'etapa de prediagnòstic i l'etapa de postdiagnòstic. Al seu torn, ambdues etapes es divideixen en diverses subetapes segons la fase de la malaltia en què ens trobem i sobre les quals podrem actuar mitjançant l'aplicació de l'activitat física que corresponga a cada període (Courneya i altres, 2001).

Anteriorment, hem parlat de la importància de l'activitat física en la prevenció primària del càncer, però l'activitat física és igual o més important en la segona etapa de la història natural del càncer, en l'etapa postdiagnòstic. En els últims anys, l'activitat física ha demostrat una capacitat molt important com a mètode de rehabilitació entre els supervivents de càncer. Els beneficis que aporta l'activitat física per a aquesta població són molt importants. Es tracta de beneficis com ara l'augment de l'interval lliure de malaltia, l'augment de la força muscular, l'augment de la capacitat aeròbica i, per descomptat, l'augment de la qualitat de vida (Courneya i altres, 2003).

\subsection{Activitat física i prevenció primària del càncer}

En aquest apartat aprofundirem en l'evidència científica/epidemiològica de la prevenció primària d'alguns tipus de càncers, tal com s'ha introduït en l'apartat 3. S'ha dit que el $35 \%$ de totes les morts mundials per càncer (és a dir, quasi 2,5 milions dels set que moren cada any) es podrien prevenir modificant els factors de risc relacionats amb l'estil de vida. De fet, un $2 \%$ de totes les morts per càncer estan relacionades amb la inactivitat física $\mathrm{i}$ un altre $2 \%$ es troba relacionat amb l'obesitat (Weiss i altres, 2007). 


\subsubsection{Càncer de mama}

Al món es diagnostiquen aproximadament 1,4 milions de dones amb càncer de mama cada any (Jemal i altres, 2011). A Espanya, tenim una incidència de 29 casos anuals per cada 100.000 dones, que equival a una xifra total de més de 25.000 nous casos de càncer de mama cada any (Ferlay i altres, 2014). Afortunadament, les modernes tècniques de diagnòstic precoç, així com la implantació d'equips multidisciplinaris encarregats d'aplicar un tractament individualitzat a cada cas, han aconseguit supervivències globals a Europa properes al 90\% per al càncer de mama (Gondos i altres, 2008).

Són múltiples els estudis que relacionen l'activitat física amb una reducció del risc de patir un càncer de mama, i globalment atribueixen a aquesta relació una reducció del risc de patir-lo d'entre el 20\% i el 40\% (Frank i altres, 2005; Friedenreich, 2011).

Així mateix, s'han investigat nombroses variables que relacionen l'exercici físic amb el càncer de mama. S'ha vist que aquesta reducció del risc és més accentuada quan practiquem activitat física recreativa d'intensitat moderada-alta, i sorprenentment es produeix una disminució del risc més elevada en pacients amb un índex de massa corporal més baix (Friedenreich, 2011).

\subsubsection{Càncer endometrial}

El càncer endometrial, sobretot la variant d'adenocarcinoma, constitueix el tercer càncer en ordre de frequiència en la dona. Al món es diagnostiquen 275.000 nous casos a l'any i la supervivència en els estadis inicials és del $68 \%$ en països occidentals. A Espanya, es diagnostiquen més de 5.000 casos nous a l'any, amb una incidència anual de 5,8 casos per cada 100.000 dones (Ferlay i altres, 2014). Són molts els factors de risc que contribueixen a aquest càncer, com ara l'obesitat, la teràpia hormonal, la nul-liparitat i la diabetis, entre d'altres (MacMahon, 1974).

Des del punt de vista de l'activitat física, hi ha moderada evidència científica del fet que l'activitat física recreativa produeix una reducció del risc de patir un càncer d'endometri d'entre el 23\% i el 29\%. Aquesta disminució sembla independent de l'índex de massa corporal (Voskuil, 2007).

\subsubsection{Càncer d'ovari}

Mundialment, apareixen més de 200.000 nous casos de càncer d'ovari a l'any, amb una mortalitat associada anual de 125.000 dones. La supervivència als Estats Units global per a tots els estadis és del $47 \%$ ( $>90 \%$ per a estadis inicials i $<20 \%$ per a estadis avançats). A Espanya, constitueix la cinquena neoplàsia maligna de la dona en ordre de freqüència. S'hi diagnostiquen 3.236 nous casos i moren 1.878 dones cada any (Ferlay i altres, 2014; Olsen i altres, 2007).

No hi ha molts estudis que relacionen l'activitat física amb el risc de patir un càncer d'ovari, però la poca evidència científica trobada atribueix a aquesta una disminució del risc de patir un càncer d'ovari del 19\%. Sembla que aquesta disminució del risc és independent de l'índex de massa corporal i de la presa d'anticonceptius orals (Olsen i altres, 2007). 


\subsection{Activitat física i efectes secundaris dels tractaments del càncer}

Els objectius que pretén aconseguir el tractament del càncer són principalment la curació, la millora dels símptomes i, òbviament, la prevenció de les recaigudes. Per a aconseguir tot això, en la majoria dels casos és necessari combinar dos o més tractaments al mateix temps. Per tant, el tractament del càncer és de tipus multimodal. Desgraciadament, els tractaments emprats per separat o de forma combinada produeixen un efecte beneficiós sobre el tumor en la majoria d'ocasions, però al mateix temps causen un efecte deleteri sobre la resta de l'organisme. Així, podem trobar els següents efectes secundaris sobre l'organisme segons el mètode de tractament emprat:

\subsubsection{Seqüeles de la cirurgia oncològica}

Actualment, la cirurgia oncològica constitueix la pedra angular sobre la qual se sosté el tractament dels tumors sòlids. Es requereixen unitats quirúrgiques multidisciplinàries per a aconseguir els resultats esperats en termes d'efectivitat i de seguretat per al pacient (Llueca i altres, 2015).

Són múltiples les seqüeles dels tractaments quirúrgics segons el tipus de tumor, de la localització i de l'estadi. Potser entre les seqüeles quirúrgiques més freqüents i més estudiades es troben els limfedemes, tant de membres superiors com d'inferiors, secundaris al tractament dels tumors de pit i dels tumors ginecològics respectivament. Respecte a l'edema de membres superiors, cal afirmar que, com més agressiva és l'acció quirúrgica, més seqüeles trobarem en forma d'edema de membre superior i alteracions de la cintura escapular (dolor en la mobilització del muscle, limitació de la rotació del muscle, rigidesa pectoral, etc.). Aquests efectes secundaris podran aparèixer immediatament després de la cirurgia o en el transcurs dels anys posteriors al tractament quirúrgic (Yang i altres, 2015).

De la mateixa manera, com a seqüela del tractament dels tumors ginecològics, apareix amb molta frequiència l'edema de membres inferiors, sobretot si hi ha hagut dissecció de les cadenes limfàtiques pelviana i aòrtiques.

El tractament actual dels limfedemes i de la incapacitat motora, sobretot del membre superior després del tractament quirúrgic del càncer de mama, es basa en els exercicis de rehabilitació.

Amb la incorporació de les tècniques de detecció del gangli sentinella, que fan innecessària la limfadenectomia completa tant en tumors de mamella com en els ginecològics, s'han minimitzat en gran part els limfedemes produïts pel tractament quirúrgic d'aquests tumors.

\subsubsection{Seqüeles de la quimioteràpia}

Els quimioteràpics són compostos que actuen sobre les cèlllules cancerígenes, que no són més que la malignització de cèlllules sanes. Per la qual cosa, si el quimioteràpic actua sobre determinats processos fisiològics de les cèllules cancerígenes per a destruir-les, també actuarà en major o en menor grau sobre les cèlllules sanes perquè aquestes comparteixen 
processos metabòlics amb les cèl·lules del tumor. Per això, els tractaments quimioteràpics s'associen a una sèrie d'efectes sobre la resta de l'organisme que es denominen efectes tòxics o secundaris. Segons el fàrmac emprat, els efectes secundaris més freqüents són els següents:

- Antraciclines. Els compostos derivats de les antraciclines (doxorrubicina) que s'empren per al tractament dels càncers de mama, mielomes, sarcomes, limfomes i ovari, posseeixen un elevat índex de cardiotoxicitat. Poden produir cardiotoxicitat aguda en forma de taquicàrdies $\mathrm{o}$, fins $\mathrm{i}$ tot, isquèmies miocàrdiques per dany sobre el teixit muscular del cor, o produir insuficiències cardíaques a llarg termini (Swain i altres, 2003).

Per tant, és aconsellable que, quan es vulga practicar qualsevol activitat física durant o després del tractament amb antraciclines, siga recomanada una prova d'esforç, així com una ecocardiografia per a valorar l'estat del cor.

- Taxans i compostos derivats del platí. Aquests compostos s'empren molt sovint per al tractament de qualsevol tipus de tumors des de la seua introducció en els anys vuitanta i noranta, on van demostrar que podien provocar l'augment de la supervivència de càncers com ara el d'ovari (Llueca, 2012).

Els efectes secundaris d'aquests compostos són múltiples, però els principals són la neutropènia, trombocitopènia, nàusees i vòmits $i$, sobretot, les neuropaties perifèriques.

\subsubsection{Seqüeles de la radioteràpia}

Actualment, quasi la meitat dels tumors necessiten tractament radioterapèutic. La radioteràpia en forma de radiació ionitzant produeix dany tissular perquè es danya l'estructura de l'ADN cel·lular i s'impedeix la replicació cel·lular. Amb el transcurs dels anys, els efectes secundaris de la radioteràpia han anat disminuint amb l'evolució de la tecnologia. Potser un dels efectes secundaris més importants i que ha descendit en l'actualitat l'ha constituït la cardiotoxicitat que es donava en les pacients a les quals s'irradiava el tòrax després d'un càncer de mama. Afortunadament, amb l'evolució de la tecnologia i amb la disminució de les taxes de radiació, aquests efectes cardiotòxics han anat desapareixent, tot i que encara persisteixen altres efectes de la radioteràpia sobre el teixit muscular perifèric en forma de fibrosi i de dolor muscular. Aquests efectes requereixen una rehabilitació específica i gradual per a poder-los vèncer (Carver i altres, 2007; Stubblefield, 2011).

\subsubsection{Seqüeles dels tractaments endocrins}

Els tractaments endocrins s'han emprat per al tractament de tumors amb receptors hormonals d'estrògens i progestàgens. Entre aquests, els inhibidors de l'aromatasa i el tamoxifén són els més utilitzats. Com a efectes secundaris d'aquests tractaments, podem trobar el dolor musculoesquelètic, sobretot amb els inhibidors de l'aromatasa, els problemes cardíacs i la predisposició al càncer d'endometri secundari amb el tamoxién. Amb tot, aquests tractaments àmpliament emprats en tumors com el de pit, han augmentat la supervivència a aquests càncers des de la seua introducció i el risc-benefici del seu ús està àmpliament justificat (Amir i altres, 2011). 


\subsubsection{Seqüeles dels tractaments biològics diana-específics o target}

El concepte agent biològic diana-específic o target fa referència a fàrmacs que actuen directament sobre proteïnes o mecanismes implicats en la proliferació i creixement de les cèl-lules tumorals. De tots aquests, els més comunament utilitzats són el Bevacizumad i el Trastuzumab.

El Trastuzumab és un anticòs monoclonal inhibidor de l'HER-2. Aquest receptor HER2 , que facilita el creixement del tumor, és positiu en el $30 \%$ dels càncers de mama. El Trastuzumab ha mostrat un augment de la supervivència quan s'empra en aquests tumors però a costa d'uns efectes secundaris a vegades importants, sobretot en forma de cardiotoxicitat.

El Bevacizumab, cada vegada més emprat en diferents tumors ginecològics com ara el d'ovari o de cèrvix, i també en els de pulmó, ronyó i còlon, és un inhibidor de l'angiogènesi tumoral, és a dir, inhibeix el creixement dels vasos amb els quals es nodreix el tumor, provocant per tant la necrosi o mort d'aquest. Com a efectes secundaris més importants del tractament, apareixen la hipertensió i la perforació intestinal espontània (Carver i altres, 2007).

Com ja hem dit anteriorment, la supervivència dels malalts de càncer ha augmentat molt en les últimes dècades gràcies a un diagnòstic precoç, que es duu a terme cada vegada més prompte, i a la introducció de tractaments agressius que han modificat el pronòstic d'aquesta malaltia. També hem vist que les seqüeles d'aquests tractaments poden arribar a ser molt greus, però són necessàries per al control de la malaltia. Com a efectes secundaris més freqüents d'aquests tractaments, trobem la fatiga, el dolor musculesquelètic, complicacions cardiovasculars i pulmonars, alteracions immunitàries, gastrointestinals i cutànies.

\begin{tabular}{|c|c|c|}
\hline Sistema & $\begin{array}{l}\text { Efectes del càncer/Efectes } \\
\text { secundaris del tractament }\end{array}$ & Efectes de l'exercici \\
\hline $\begin{array}{l}\text { Cardiovascu } \\
\text {-lar }\end{array}$ & $\begin{array}{l}\text { ฟVO2 max, } \text { resistència } \\
\text { acrobàtica, cardiopatia, HTA }\end{array}$ & $\uparrow$ VO2 max, $\uparrow$ resistència aeròbica \\
\hline Muscular & $\begin{array}{l}\text { miàlgia, artralàgia, caqueixa, } \\
\text { oporosi, } \downarrow \text { massa magra }\end{array}$ & $\begin{array}{l}\uparrow \text { massa muscular, } \uparrow \text { força i } \\
\text { resistència, } \downarrow \text { dolor, } \uparrow \text { recanvi ossi }\end{array}$ \\
\hline Respiratori & $\begin{array}{l}\text { disnea, } \downarrow \text { capacidad pulmonar, } \\
\text { total }\end{array}$ & $\begin{array}{r}\uparrow \text { capacitat pulmonar, } \\
\downarrow \text { disnea }\end{array}$ \\
\hline Neurològic & $\begin{array}{l}\text { neuropatia, pèrdua de } \\
\text { coordinació }\end{array}$ & millora de la coordinació \\
\hline Immunològic & $\uparrow$ productes inflamatoris (IL-6) & efecte antiinflamatori \\
\hline Endocrí & $\uparrow$ resistència insulina, $\uparrow$ pes & control pes, $\uparrow$ sensibilitat insulina \\
\hline
\end{tabular}

Figura 3. Efectes del càncer/efectes secundaris del tractament i efectes de l'exercici físic sobre els diferents sistemes fisiològics. 
La introducció de l'exercici físic durant el tractament del càncer s'ha de dur a terme amb precaució i possiblement no puga introduir-se en tots els malalts de càncer. No obstant això, en l'actualitat hi ha una evidència creixent del fet que la realització d'exercicis aeròbics moderats com ara caminar o anar amb bicicleta pot tenir efectes beneficiosos durant el tractament, tant en l'aspecte fisiològic, en fer disminuir els efectes secundaris o minimitzarlos, com en l'aspecte psicològic, ja que ens fa sentir millor (Schmitz i altres, 2010, 2012).

\subsection{Activitat física després del tractament}

L'exercici pot beneficiar els supervivents del càncer en recondicionar i revertir els efectes produïts per la malaltia i els seus tractaments. Així, l'exercici després del tractament pot recuperar tot allò que s'ha perdut durant el procés que comença en el diagnòstic i finalitza en acabar l'últim cicle de tractament, ajudant tant en l'aspecte fisiològic com en el psicològic. Els efectes beneficiosos de l'exercici es mostren en la figura 3 de la pàgina anterior.

\section{Conclusió}

En l'actualitat hi ha una gran evidència científica del fet que l'exercici físic, per si sol o en combinació amb la dieta i el normopès, són capaços de disminuir el risc de patir algun determinat tipus de càncer com el de mama i el d'endometri, i també el d'ovari, encara que aquest últim amb menor evidència científica. Els mecanismes etiològics últims que relacionen l'exercici físic amb la reducció del risc de patir determinats càncers encara romanen ocults, però s'han vist implicades diverses rutes biològiques com són la resistència a la insulina, els factors inflamatoris dels adipòcits, els factors hormonals i les alteracions immunològiques.

En els supervivents al càncer, l'exercici físic aporta efectes beneficiosos com ara la millora de la composició corporal, de l'estat físic, de l'ansietat, de la qualitat de vida i de l'autoestima. També s'ha relacionat l'exercici físic amb un augment de la supervivència en determinats tipus de càncers com el de mama, malgrat que açò últim resta encara per confirmar.

Finament, podem dir que l'exercici físic, supervisat per un professional de l'educació física i adaptat a cada una de les etapes naturals de la malaltia, és capaç de millorar i revertir els efectes perniciosos tant del càncer com dels tractaments administrats.

\section{BIBLIOGRAFIA}

AmiR, E. i altres (2011): «Toxicity of adjuvant endocrine therapy in postmenopausal breast cancer patients: a systematic review and meta-analysis», Journal of the National Cancer Institute, 103(17), 1299-1309.

CARver, J.R. i altres (2007): «ASCO Cancer Survivorship Expert Panel. American Society of Clinical Oncology clinical evidence review on the ongoing care of adult cancer survivors: cardiac and pulmonary late effects», Journal of Clininc Oncology, 25(25), 3991-4008.

CASH, S.W. i altres (2013): «Recent physical activity in relation to DNA damage and repair using the comet assay», Journal of Physical Activity \& Health, 11(4), 770-6. 
CASPERSEn, C.J. i altres (1985): «Physical activity, exercise, and physical fitness: definitions and distinctions for health-related research», Public Health Reports, 100(2), 126-131.

Courneya K.S. (2003): «Exercise in cancer survivors: an overview of research», Medicine \& Science in Sports \& Exercice, 35(11), 1846-1852.

Courneya, K.S. i C.M. FriedenReICH (2001): «Framework PEACE: an organizational model for examining physical exercise across the cancer experience», Annals of Behavioral Medicine, 23(4), 263-272.

DALEY A.J. i altres (2007): «Randomized trial of exercise therapy in women treated for breast cancer», Journal of Clininc Oncology, 25, 1713-21.

FRANK, L. i altres (2005): «Effects of exercise on metabolic risk variables in overweight postmenopausal women: a randomized clinical trial», Obesity Research, 13(3), 615-625.

Friedenreich, C.M. (2010): «The role of physical activity in breast cancer etiology», Seminars in Oncology, 37(3), 297-302.

- (2011): «Physical activity and breast cancer: review of the epidemiologic evidence and biologic mechanisms. Recent Results», Cancer Research, 188, 125-139.

GATTI, R. i altres (2012): «IGF-I/IGFBP system: metabolism outline and physical exercise», Journal Endocrinoligal Investigation, 35(7), 699-707.

Gondos, A. i altres (2008): «EUNICE Survival Working Group. Recent trends in cancer survival across Europe between 2000 and 2004: a model-based period analysis from 12 cancer registries», European Journal of Cancer, 44(10), 1463-1475.

Hewitt, M. i altres (eds.) (2006): From Cancer Patient to Cancer Survivor: Lost in Transition, Washington, National Academies Press.

Holmes, M. i altres (2005): «Physical activity and survival after breast cancer diagnosis», The Journal of the American Medial Association, 293, 2479-86.

IL'YASOVA, D. i altres (2005): «Circulating levels of inflammatory markers and cancer risk in the health aging and body composition cohort», Cancer Epidemiology, Biomarkers \& Prevention, 14(10), 2413-8.

FERLAY, J.I. i altres (2014): «Cáncer incidence and mortality worldwide: sources, methods and major patterns in GLOBOCAN 2012», International Journal of Cancer, 1, 136(5), E359-86.

Jemal, A. i altres (2011): «Global cancer statistics», CA: A Cancer Journal for Clinicals, 61, 69-90.

KeY, T.J. i altres (2013): «Sex hormones and risk of breast cancer in premenopausal women: a collaborative reanalysis of individual participant data from seven prospective studies», The Lancet Oncology, 14(10), 1009-19.

LlueCA, J.A. (2012): Epidemiologia de las neoplasias malignas de ovario en Tarragona, 1980-2005, tesi doctoral, Tarragona, Universitsat Rovira i Virgili.

LluecA, J.A. i altres (2015): «MUAPOS Working Group Effectiveness and Safety of Cytoreduction Surgery in Advanced Ovarian Cancer: Initial Experience at a University General Hospital», Journal of Clininical Gynecology \& Obstetrics, 4(3), 251-257.

MacMahon, B. (1974) «Risk factors for endometrial cancer», Gynecologic Oncology, 2(2-3), 122-129.

Olsen, C.M. i altres (2007): «Australian Ovarian Cancer Study Group. Recreational physical activity and epithelial ovarian cancer: a case-control study, systematic review, and meta-analysis», Cancer Epidemiology, Biomarkers \& Prevention, 16(11), 2321-2330.

Pollock, R.E. i altres (eds.) (2003): UICC Manual of Clinical Oncology, Hoboken, Wiley-Liss, 917.

SATO, Y. i altres (2003): «Increase of human MTH1 and decrease of 8-hydroxydeoxyguanosine in leukocyte DNA by acute and chronic exercise in healthy male subjects», Biocheminal and Biophysical Research Communications, 305(2), 333-8. 
Schmiтz, K.H. i altres (2010): «American College of Sports Medicine roundtable on exercise guidelines for cancer survivors», Medicine \& Science in Sports Exercice, 42, juliol, 1409-26.

Sснмітz, K.H. i altres (2012): «Prospective surveillance and management of cardiac toxicity and health in breast cancer survivors», Cancer, 118(S8), 2270-2276.

Stubblefield, M.D. (2011): «Radiation fibrosis syndrome: neuromuscular and musculoskeletal complications in cancer survivors», $P M \& R$ : The journal of injury, funtion and rehabilitation, 3(11), 1041-1054.

SwaIn, S.M. i altres (2003): «Congestive heart failure in patients treated with doxorubicin: a retrospective analysis of three trials», Cancer, 97(11), 2869-2879.

Thompson, W.R. i altres (eds.) (2010): ACSM's Guidelines for Exercise Testing and Prescription, Philadelphia, Lippincott, Williams \& Wilkins.

Voskuil, D.W. i altres (2007): «Task Force Physical Activity and Cancer. Physical activity and endometrial cancer risk, a systematic review of current evidence», Cancer Epidemiology, Biomarkers \& Prevention, 16(4), 639-648.

Weiderpass, E. (2010): «Lifestyle and cancer risk», Journal of Preventive Medicine \& Public Health, 43, 459-471.

WeIss, E.P. i J.O. Holloszy (2007): «Improvements in body composition, glucose tolerance, and insulin action induced by increasing energy expenditure or decreasing energy intake», The Journal of nutrition, 137(4), 1087-1090.

YANG, E.J. i altres (2010): «Longitudinal change of treatmentrelated upper limb dysfunction and its impact on late dysfunction in breast cancer survivors: a prospective cohort study», Journal of Surgical Oncology, 101(1), 84-91.

\section{BIONOTA}

\section{Josep Antoni Llueca Abella}

MD PhD. És Coordinador de la UMCOAP (Unidad Multidisciplinar de Cirurgia Oncològica AbdominoPèlvica) en el Servei de Ginecologia i Obstetrícia de l'Hospital General Universitari de Castelló i Professor Associat de l'UJI. Doctor per la Universitat Rovira i Virgili de Tarragona, ha especialitzat la seua recerca en l'epidemiologia del càncer ginecològic. 